\title{
Optimal Design and Simulation of Solar Photovoltaic Powered Cathodic Protection for Underground Pipelines in Libya
}

\author{
Mustafa A. Al-Refai \\ Electrical and Electronic Department, Faculty of Engineering, University of Tripoli, Libya
}

\begin{abstract}
In Libya, pipelines are being used as means of transferring hydrocarbon from wellheads to export sea ports, refineries, storage tanks, steel factory and power plants. Steel pipeline is widely used because it is the safest means of transporting hydrocarbon and other oil products as well as its cost effective. However, one of the challenges facing oil and gas sector is corrosion on infrastructure facilities and processing units. Cathodic-protection (CP) is an electrical method used to protect metallic body in contact with the earth from corrosion. A photovoltaic (PV) provides a reliable solution for powering remote CP stations, enabling the placing of CP units in any location along the underground pipeline, thus ensuring optimal current distribution for the exact protection requirements. In this paper the sizing of the system is determined based on the electrical power needed for the catholic protection, characteristics of the used PV module and the meteorological data of the installation site. Matlab/Simulink and PVsyst V6.43 software are used as tools for optimal design, sizing and simulation of the PV powered cathodic protection system components. In addition to that estimation of system cost was investigated and compared with the conventional system. The results show that using solar energy powered cathodic protection system for underground pipelines is practical and very beneficial besides being economical, especially considering the rapid decreasing in the prices of PV systems components and the increasing of its efficiencies and reliability.
\end{abstract}

Key words: Libya, PV, CP, solar energy, Matlab/Simulink, PVsyst.

\section{Introduction}

Crude oil and natural gas transfer pipelines pass through Libyan's desert areas where a frequent problem in cathodic protection (CP) is that extending the normal electric power supply from the utility grid would be very costly.

Libya is blessed with a rich and reliable supply of solar energy and with an average sunshine duration of more than 300 days per year. In this paper, the study has been conducted for a pipeline cathodic protection site Ras-Lanuf which is located on the Gulf of Sirit of Libya. The pipeline 36" is running from Amal field to Ras Lanuf Tank Farm for a distance of approximately $273 \mathrm{~km}$, and buried in the desert sand. With coordinates are $30^{\circ} 19^{\prime} \mathrm{N}$ latitude and $18^{\circ} 5^{\prime} \mathrm{E}$ longitude.

Corresponding author: Mustafa A. Al-Refai, Ph.D., professor, research fields: electrical power system, electrical machines, power electronics and renewable energy.
By using solar photovoltaic (PV) system provides a reliable solution for powering remote cathodic protection stations, enabling the placing of cathodic protection units in any location, thus ensuring an optimal current distribution for the exact protection system requirements.

Corrosion is defined as an electrochemical process in which a current leaves a metal body at the anode area, passes through an electrolyte, and reenters the metal structure at the cathode area. Corrosion in pipeline leads to material loss, gas and oil leakage, and interruption in gas and oil supply. In addition, problems and failures of pipeline networks not only have an economic cost; it can also present a threat to life and the environment [1-2].

$\mathrm{CP}$ is an electrical technique used to protect metallic bodes in contact with the earth from corrosion by minimizing the potential difference between anode and 
cathode. This is achieved by supplying electrical current to the structure to be protected from some outsider source. When enough current is applied, the whole structure will be at one potential level; thus, anode and cathode will disappear.

The simplest method to apply cathodic protection is by connecting the metal body to be protected with another more easily corroded metal to act as the anode of the electrochemical cell [3]. There are two main types of cathodic protection systems, one is the galvanic cathodic protection systems and the other is the impressed current cathodic protection (ICCP) systems. Both types have anodes (from which current flows into the electrolyte), a continuous electrolyte from the anode to the protected metal structure, and an external metallic connection.

The potential for the use of ICCP was first recognized by Cotton in 1958 [4]. Since that time, the performance and development of various platinum surfaced anodes has been widely covered in the literature [5]. The correct application of cathodic protection can extend the design life of oil, gas and water underground pipeline networks, saving the energy and the money necessary to build a new one. Therefore, cathodic protection is a tool to achieve energy efficiency.

In the impressed current cathodic protection system, it is possible to use the photovoltaic system as a power supply.

The objectives of this paper are designing, and simulation of solar photovoltaic powered cathodic protection system for underground pipelines transporting hydrocarbon and other oil products in Libya. The design was based on the pipeline dimensions, the percentage of protected surface area, the electrical parameters of pipeline surrounding environments, characteristics of the used PV module and the meteorological data of the site of installation. ICCP system design calculation methodologies adopted a step-by-step approach and to validate the design a simulation is carried out using
Matlab/Simulink and PVsyst V6.43 software.

\section{Principles of Cathodic Protection}

Oil and gas pipelines have been made from its primary ore metal oxides with a natural tendency to revert to that state under the action of oxygen and water. This behavior is called corrosion. This is an electrochemical process that involves the passage of small scale electrical currents [6]. The change from the metallic to the combined form occurs by an "anodic" reaction.

$$
\mathrm{Fe} \rightarrow \mathrm{Fe}^{++}+2 \mathrm{e}^{-}
$$

This reaction produces free electrons, which pass within the metal to another position, on the metal surface (the cathode), where it is consumed by the cathodic reaction.

In acid solutions the cathodic reaction is [7]:

$$
2 \mathrm{H}^{+}+2 \mathrm{e}^{-} \rightarrow \mathrm{H}_{2}
$$

Corrosion occurs at the anode but not at the cathode. The anode and cathode in a corrosion process may be consisting of two different metals connected together forming a bimetallic couple, or, as with rusting of steel, they may be close together on the same metal surface. The principle of cathodic protection is connecting an external anode to the metal surface to be protected and passing of an electrical dc current so that the whole area of the metal surface becomes cathodic and hence corrosion does not occur. The external anode may be a galvanic anode, where the current is a result of the potential difference between the two metals, or it may be an impressed current anode, where the dc current is impressed from an external power supply [8].

In electrochemical process, the electrical potential between the metal and the surrounding electrolyte with which it is in contact is made more negative, by supplying negative charged electrons, to a value at which the corroding (anodic) reactions are suppressed and only cathodic reactions can take place.

\section{Components of the ICCP System}

The main components of the ICCP system powered 
by PV solar energy are PV generator to supply dc current, DC-DC, converters used to increase or decrease the voltage produced by the solar array, batteries storage system, coated pipeline structure system and impressed current anodes. Fig. 1 shows block diagram for the whole PV powered ICCP system.

\section{Design of Cathodic Protection Systems}

The design process for cathodic protection of underground pipelines network includes the various necessary input parameters such as soil resistivity, current density protection criteria and design life. Soil resistivity is a function of soil moisture and the concentrations of ionic soluble salts and is considered the most comprehensive indicator of the soil's corrosiveness. Typically, the lower the resistivity, the higher will be the corrosiveness as indicated in the following Table 1 [9].

In this paper, a design was carried out for HAROUGE Oil Operations' Ras-Lanuf, which is located on the Gulf of Sirit of Libya. The pipeline 36" is running from Amal field to Ras Lanuf Tank Farm for a distance of approximately $273 \mathrm{~km}$, and buried in the desert sand. In this design an assumption of coating efficiency $90 \%$, design life 35 years and pipe joint length $4 \mathrm{~m}$ are considered. The electrical parameters for pipeline, anode and surrounding environments are shown in Tables 2 and 3 [10].

Design of the impressed current cathodic protection system was carried out based on the pipeline information (Tables 1-3). The procedure for the design starting with calculating the current required to cathodically protect the pipeline under consideration or change its potential to minimum value of $0.85 \mathrm{~V}$. The

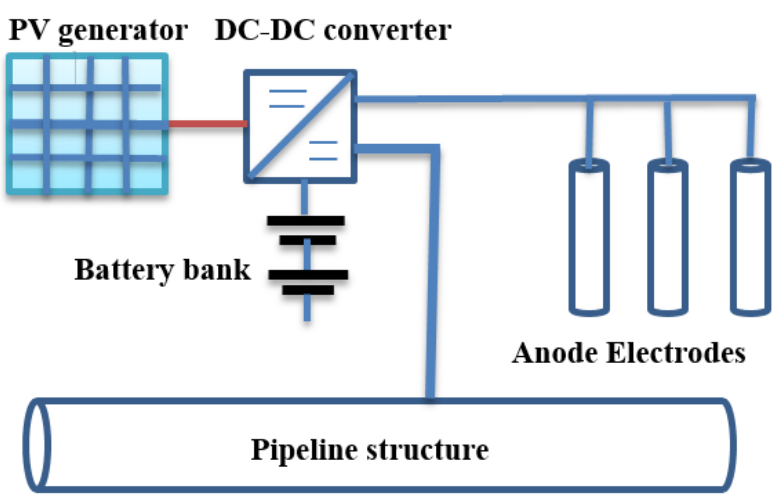

Fig. 1 Block diagram of ICCP system powered by PV.

Table 1 Soil resistivity vs. degree of corrosion [9].

\begin{tabular}{ll}
\hline Soil resistivity $(\mathrm{ohm}-\mathrm{cm})$ & Degree of corrosion \\
\hline $0-500$ & Very corrosive \\
$500-1,000$ & Corrosive \\
$1,000-2,000$ & Moderately corrosive \\
$2,000-10,000$ & Mildly corrosive \\
Above 10,000 & Negligible \\
\hline
\end{tabular}

Table 2 Electrical parameters of pipeline surrounding environments.

\begin{tabular}{lll}
\hline Environment & $J\left(\mathrm{~A} / \mathrm{m}^{2}\right)$ & $P(\Omega \cdot \mathrm{cm})$ \\
\hline Sea water & 0.008 & 10 \\
Clay, well aerated soil & 0.003 & 250 \\
Dry soil & 0.0015 & 2,000 \\
Desert & 0.0004 & 2,500 \\
Wet soil with stones & 0.006 & 120 \\
\hline
\end{tabular}


Table 3 Anode data.

\begin{tabular}{ll}
\hline Anode material & Platinum clad \\
\hline Current density & $30 \mathrm{~mA} / \mathrm{m}^{2}$ \\
Design life & 35 years \\
Anode dimension & $0.75 \mathrm{~m} \times 0.75 \mathrm{~m} \times 3.00 \mathrm{~m}$ \\
Utilization of platinum clad & $65 \% \mathrm{~kg} / \mathrm{amp}-\mathrm{yr}$ \\
Weight of anode & $30 \mathrm{~kg}$ \\
Backfill length surrounding anode & $0.5 \mathrm{~m}$ \\
Backfill diameter surrounding anode & $0.15 \mathrm{~m}$ \\
Cable wire specification & 0.0212 ohms per $100 \mathrm{ft}$ \\
\hline
\end{tabular}

current requirement depends on pipe coating quality, soil resistivity of pipeline route and total external surface area of the pipeline.

\section{Corrosion Current Calculation}

Design of ICCP starting with calculating the current required to catholically protect the pipeline under consideration or change the structure potential to minimum value of $0.85 \mathrm{~V}$. The required dc current to prevent corrosion is calculated based on the quantities of current density (which is the minimum quantity of electrical current required to prevent corrosion from occurring on the pipeline steel surface), coating quality, and soil resistivity (along the right of way and total external surface area of the pipeline) [11]. The required current $I_{R}$ was calculated using the following equation.

$$
I_{R}=A_{t} \times j_{c}
$$

where, $A_{t}$ is the total external pipeline surface area and $J_{c}$ is the current density.

The total external surface area of the pipeline can be determined using the following equation which is applied on cylindrical shape as the distributed pipeline depending on the length of the pipeline $(L)$ and the diameter of the pipeline $(D)$, surface area of pipeline. And considering the coating efficiency, $\eta_{c}=0.9$ based on the total external surface area of the pipeline is estimated as follows:

$$
A_{t}=\pi \times D \times L \times \eta_{c}
$$

where, $D=0.762 \mathrm{~m}(36 ")$, and $L=273,000 \mathrm{~m}$.

$$
\begin{gathered}
\therefore=3.142 \times 0.9144 \times 273 \times 1000 \times(1-0.9) \\
=78434.123 \mathrm{~m}^{2}
\end{gathered}
$$

The total current is required for ICCP $I_{R}$ using based on the pipe surface area and current density $j_{c}$ in Table 1 for desert environment yield.

$$
I_{R}=0.0004 \times 78434.123=31373.649 \mathrm{~mA}
$$

Next step is calculating the required number of anodes needed to meet current density limitation specified by the manufacturer, which is found as follows:

$$
N_{A}=\frac{I_{R}}{A_{t} \times j_{c}}
$$

where, $N_{A}$ is the required number of anodes and $A_{a}$, is the anode surface area estimated using Table 2 as:

$$
A_{a}=\pi \times d \times l=3.142 \times 0.75 \times 3=7.1 \mathrm{~m}^{2}(6)
$$
therefore,

$$
N_{A}=\frac{I_{R}}{A_{t} \times j_{c}}=\frac{31373.649}{7.1 \times 30}=148 \text { anodes }
$$

Then required number of anodes needed to meet 35 years intended design life based on the required current was calculated using the following formula [12].

$$
N_{A}=\frac{D_{L} I_{R}}{1000 \times A_{W}}
$$

where, $D_{L}$ is the design life and $A_{W}$ is the anode weight. Therefore,

$$
N_{A}=\frac{35 \times 31373.649}{1000 \times 30} \cong 37 \text { anodes }
$$

Additionally, anode spacing is an important design parameter that is used to ensure that maximum allowable voltage drop is not exceeded. The anode spacing can be reduced if the permissible voltage drop is exceeded by choosing anode with lower weight or increasing the number of anodes. The anode spacing $\left(A_{S}\right)$ is estimated with the following equation:

$$
A_{S}=\frac{\text { Pipeline lengt } h}{N_{a}}=\frac{273 \times 1000}{37} \cong 7378.378 \mathrm{~m}
$$


Next is calculation of interval of pipe joints to determine interval of anode bracelet that will be placed. The interval of pipe joints is given as:

$$
\begin{aligned}
\text { interval }= & \frac{A_{S}}{\text { average length of pipe joint }} \\
& =\frac{7378.378}{4}=1844.595 \text { joint }
\end{aligned}
$$

Furthermore, anode to electrolyte resistance known as resistance to earth remains a critical parameter of cathodic protection system design evaluation in predicting anode current output. The other resistances include structure to electrolyte and cabling resistance and are often neglected in design for offshore location. The resistance of a single vertical anode $R_{A}$ was calculated using the following equation [13]:

$$
R_{A}=0.00512 \times p \times \frac{\left[\ln \left(8 \times A_{l} / A_{d}\right)-1\right]}{A_{l}}
$$

where, $A_{l}$ is the anode length plus backfill, $A_{d}$ is the anode diameter plus backfill and $\rho$ is the average soil resistivity taken as $65 \Omega \cdot \mathrm{m}$ against taking the lowest value since there were no significant variations of the values.

$$
R_{A}=0.0052 \times 65 \times \frac{\left[\ln \frac{\{8 \times(3+0.5)\}}{(0.75+0.15)-1}\right]}{(3+0.5)}=0.24 \Omega
$$

Anode lead wire cable was supplied in ohms per 100 $\mathrm{ft}$ per manufacturer's specification and the cable wire resistance was computed with Eq. (14):

$$
R_{W}=\frac{\Omega L}{100 \mathrm{ft}}
$$

where, $L$ is the length of structure (pipeline) measured in $\mathrm{ft}$.

$$
\therefore R_{W}=\frac{0.00212 \times 328 \mathrm{ft}}{100 \mathrm{ft}}=0.070 \Omega
$$

The structure to electrolyte resistance $\left(R_{e}\right)$ is calculated as follows:

$$
R_{e}=\frac{R_{c}}{A_{C}}
$$

where, $R_{C}$ is the coating resistance and $A_{C}$ is the area of the coated pipeline surface. The entire pipeline length under consideration has been coated. So, $A_{C}=A_{t}$.

$$
\therefore R_{e}=\frac{18}{86405}=0.0002 \Omega
$$

The total circuit resistance was estimated using the follows formula [13].

$$
\begin{gathered}
R_{T}=R_{G}+R_{W}+R_{e} \\
\therefore R_{T}=0.24+0.070+0.0002=0.3102 \Omega
\end{gathered}
$$

The voltage requirement was calculated with following equation:

$$
V_{T}=I_{T} \times R_{T} \times 150 \%
$$

where, $V_{T}$ is the voltage output requirement and the $150 \%$ represents design factor to ensure supply voltage not below the needed voltage.

$$
V_{T}=\frac{31373.649 \times 0.3102 \times 150}{100}=14598.159 \mathrm{mV}
$$

\section{PV Generator Sizing}

ICCP system needs an external current source, and the PV generator is used as a current source for the ICCP system. The PV station is constructed in one place per section of which means that each medium has a PV station and the station is including the anodes and batteries in the same place of PV station.

\subsection{Required Power and Energy for ICCP System}

The required power $P_{R}$ for ICCP system can be calculated using the following equation;

$$
\begin{gathered}
P_{R}=I_{R} \times V_{R} \\
\therefore P_{R}=31.374 \times 14.598=457.998 \mathrm{Watt}
\end{gathered}
$$

Therefore the required energy $E_{R}$ needed for ICCP system in one day can be found as follows:

$$
\begin{gathered}
E_{R}=P_{R} \times 24 \\
E_{R}=457.998 \times 24=10991.944 \mathrm{Wh}
\end{gathered}
$$

\subsection{Power Produced from PV Generator}

The power produced $P_{P V}$ from PV generator can be determined using the following equation.

$$
\begin{array}{r}
P_{P V}=\frac{E_{R}}{\eta_{C}} \times 1.15 \times \frac{1000 \mathrm{~W}}{5400 \mathrm{Wh} / \text { day }} \\
\therefore P_{P V}=\frac{10991.944}{0.9} \times 1.15 \times \frac{1000}{5400}=2601 \mathrm{~W}
\end{array}
$$

\subsection{Number of Modules}

Factors affecting the selection of a PV module are 
the efficiency of the module and its cost. To decide whether to use poly-crystalline or mono-crystalline modules is not easy; it requires weighing costs against efficiencies. PV modules are sized depending on the peak power of one module $P_{\max }$ under standard testing conditions (STC). Specifically, STC are $1,000 \mathrm{~W} / \mathrm{m}^{2}$ solar irradiance and $25^{\circ} \mathrm{C}$.

In this design, the Canadian solar power of $400 \mathrm{Wp}$ production is selected and adopted. The parameters of the chosen PV module are given in Table 4 [14].

The number of modules $\mathrm{Nm}$ is calculated in Eq. (21) depending on the peak power of one module $P_{\max }$ which is taken as $435 \mathrm{~W}$, this value referred to:

$$
\begin{gathered}
N_{M}=\frac{P_{P V}}{P_{M}} \\
\therefore N_{M}=\frac{2601}{435} \cong 6
\end{gathered}
$$

\section{Battery Sizing and Selection}

A battery bank is used as a backup system and it maintains constant voltage across the load. It is used to power the ICCP, when the solar power is not available basically during night time and cloudy days. The energy required by ICCP was calculated and equal to $10,991.944 \mathrm{Wh}$ and the battery operating voltage is 12 $\mathrm{V}$. The required battery capacity in ampere hour $C_{A h}$ was calculated based on the values of DOD of the battery $(0.85)$ and its average (efficiency $=78$ ) using the following equation.

Battery capacity in Ah

$$
=\frac{\text { autnomy days } \times E_{\text {load }}}{V_{\text {battery }} \times D O D \times \eta_{\text {inverter }}}
$$

where:

Autonomy days $=1$;

$E_{\text {load }}=$ energy consumption Wh/day;

DOD $=$ battery depth of discharge $=0.75$;

$\eta_{\text {battery }}=$ efficiency of battery $=85 \%$.

$\therefore$ battery capacity $A h=\frac{1 \times 10991.944 \mathrm{Wh}}{0.78 \times 0.85 \times 12}$

$$
=1381.592 \mathrm{Ah} \approx 1382 \mathrm{Ah}
$$

Two $400 \mathrm{Ah}, 6 \mathrm{~V}$ batteries in series yield $12 \mathrm{~V}$ at 400
Ah.

series battery capacity $=\frac{1382}{400}$

$$
=3.455 \approx 4 \text { batteries }
$$

Therefore the total number of batteries in a battery bank (consisting of 4 batteries) will provide a capacity of 1,600 Ah.

\section{Simulink Output of Designed Grid-Connected PV Panel}

A block diagram of the PV model using Simulink is given in Fig. 2. The block in Fig. 2 contains the sub models connected to build the final model. Variable temperature $(T)$, and variable solar irradiation level $(G)$ are the inputs to the PV model. The equation of the PV output current $\boldsymbol{I}$ is expressed as a function of the array voltage $V$ as follows:

$$
I=I_{p h}-I_{D}=I_{p h}-I_{s a t}\left[e \frac{q\left(V+I R_{s}\right)}{n k T}-1\right]
$$

where:

$I_{p h}$ the light current (A), $I_{s a t}$ the diode reverse saturation current (A), $R_{s}$ the series resistance $(\Omega), V$ the operation voltage $(\mathrm{V})$, and $I$ the operation current (A).

$q$ = charge of one electron $\left(1.602 \times 10^{-19} \mathrm{C}\right)$.

$n=$ diode idealizing factor, and $k=$ Boltzmann's constant $\left(1.38 \times 10^{-23} \mathrm{~J} / \mathrm{K}\right)$.

$T=$ junction temperature in Kelvin.

The modeling of the PV array for Matlab/Simulink environment is discussed in Ref. [15].

The final PV system design consists of six modules connected in parallel with manufacturer's specified nameplate as shown in Table 4. The I-V and P-V outputs characteristics of PV module with varying irradiation and constant temperature are shown in Figs. 3 and 4. The P-V and I-V outputs characteristics of PV module with varying temperature at constant irradiation are shown in Figs. 5 and 6. The results are verified and found matching with the manufacturer's data sheet output curves. 


\section{Underground Pipelines in Libya}

Table 4 Specifications for solar panels.

\begin{tabular}{ll}
\hline Electrical specifications $\left(\mathrm{STC}=25^{\circ} \mathrm{C}, 1,000 \mathrm{~W} / \mathrm{m}^{2}\right.$ irradiance and $\left.\mathrm{AM}=1.5\right)$ \\
\hline Model & SPR-E20-435-COM \\
\hline Max system voltage & $1000 \mathrm{~V}$ \\
Max peak power $P_{\max }$ & $435 \mathrm{~W}( \pm 3 \%)$ \\
Maximum power point voltage $V_{\mathrm{mpp}}$ & $72.9 \mathrm{~V}$ \\
Maximum power point current $I_{\mathrm{mpp}}$ & $5.97 \mathrm{~A}$ \\
Open circuit voltage $V_{o c}$ & $85.6 \mathrm{~V}$ \\
Short circuit current $I_{s c}$ & $6.43 \mathrm{~A}$ \\
Module Efficiency $(\%)$ & $20.3 \%$ \\
Temperature coefficient of $V$ & $-235.5 \mathrm{mV} \%{ }^{\circ} \mathrm{C}$ \\
Temperature coefficient of $I_{s c}$ & $2.6 \mathrm{~mA} \% /{ }^{\circ} \mathrm{C}$ \\
Temperature coefficient of $P_{\max }$ & $-0.35 \% /{ }^{\circ} \mathrm{C}$ \\
\hline
\end{tabular}

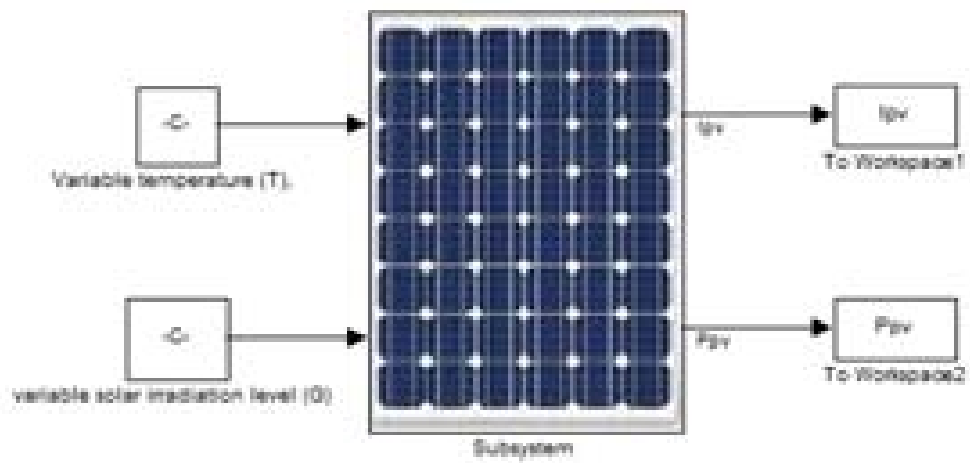

Fig. 2 Simulink model of PV module.

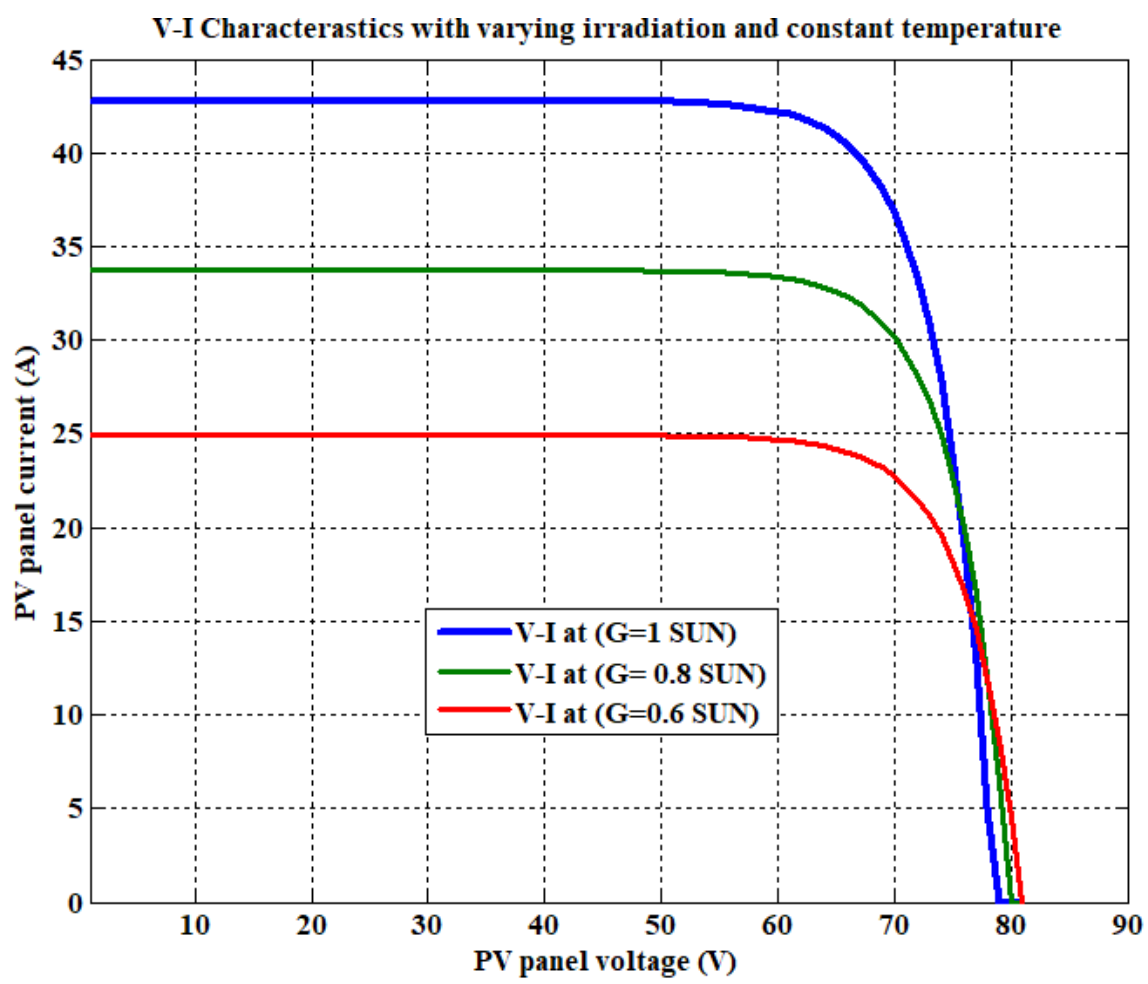

Fig. 3 V-I characteristic curves at different insolation levels ( $G=0.6 \mathrm{SUN}, 0.8 \mathrm{SUN}, 1 \mathrm{SUN})$ for 6 modules in parallel. 

Underground Pipelines in Libya

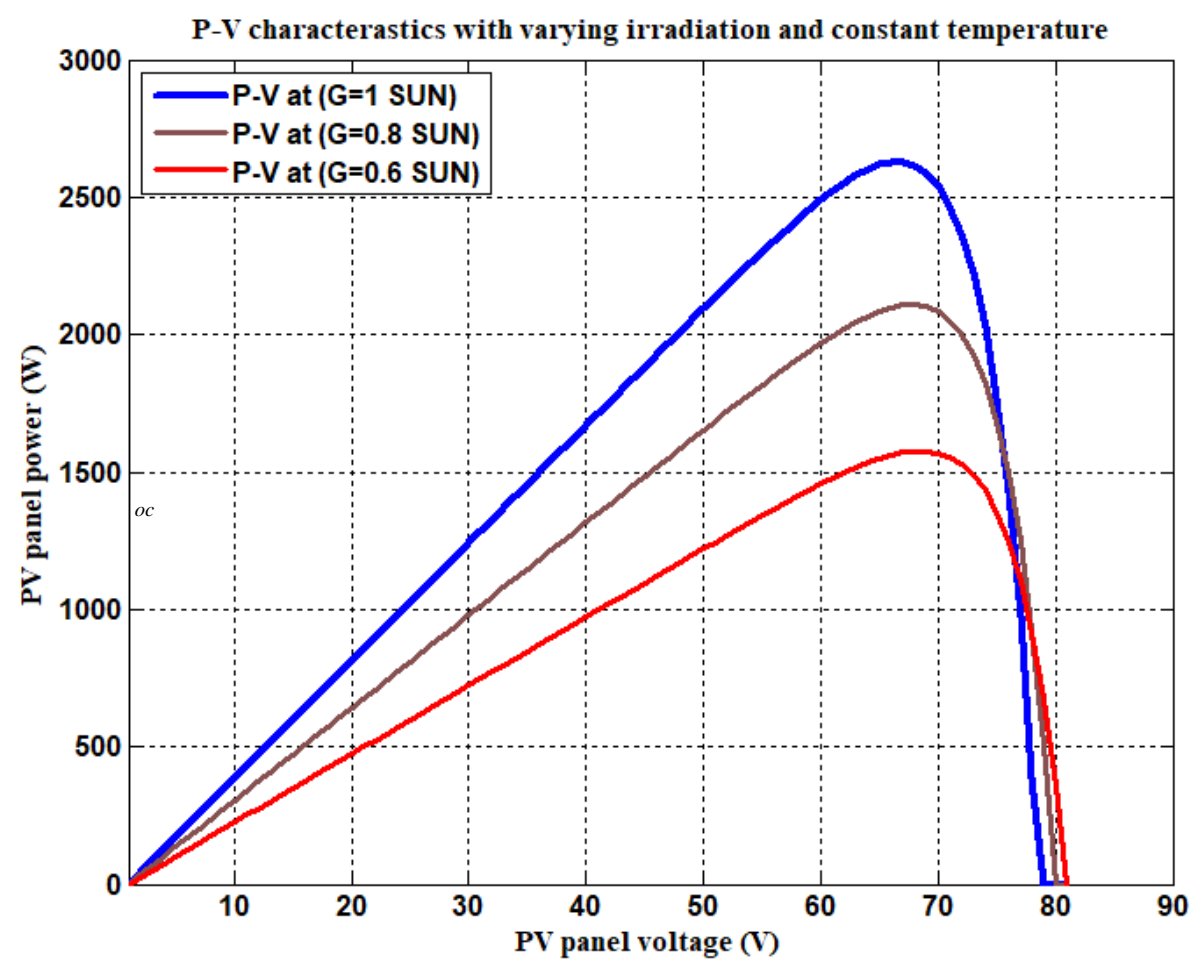

Fig. 4 P-V characteristic curves at different insolation levels $(G=0.6$ SUN, 0.8 SUN, 1 SUN) for 6 modules in parallel.

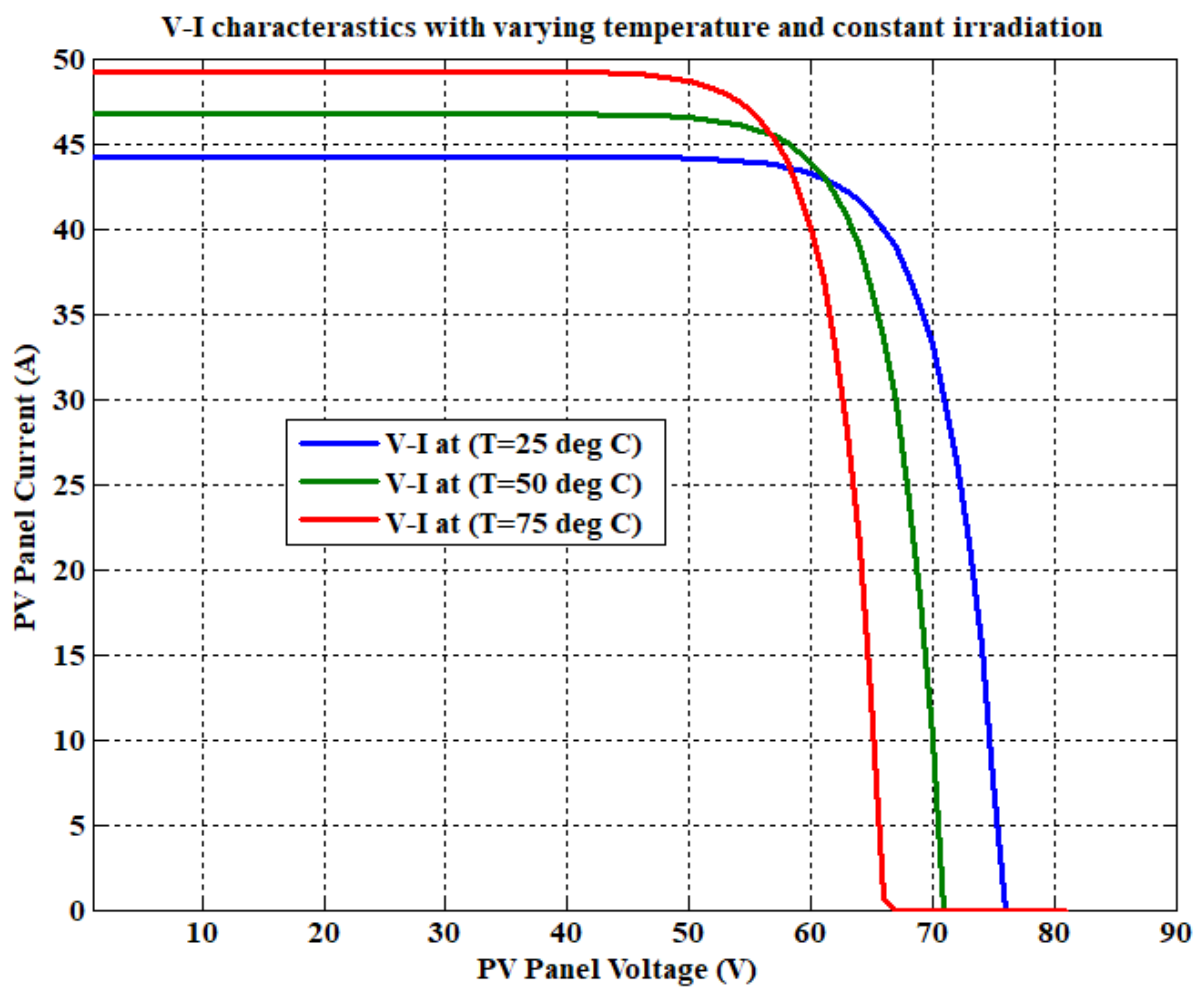

Fig. 5 V-I characteristic curves at different cells working temperature $\left(T_{c}=25^{\circ} \mathrm{C}, 50{ }^{\circ} \mathrm{C}, 75^{\circ} \mathrm{C}\right)$ for 6 modules in parallel. 


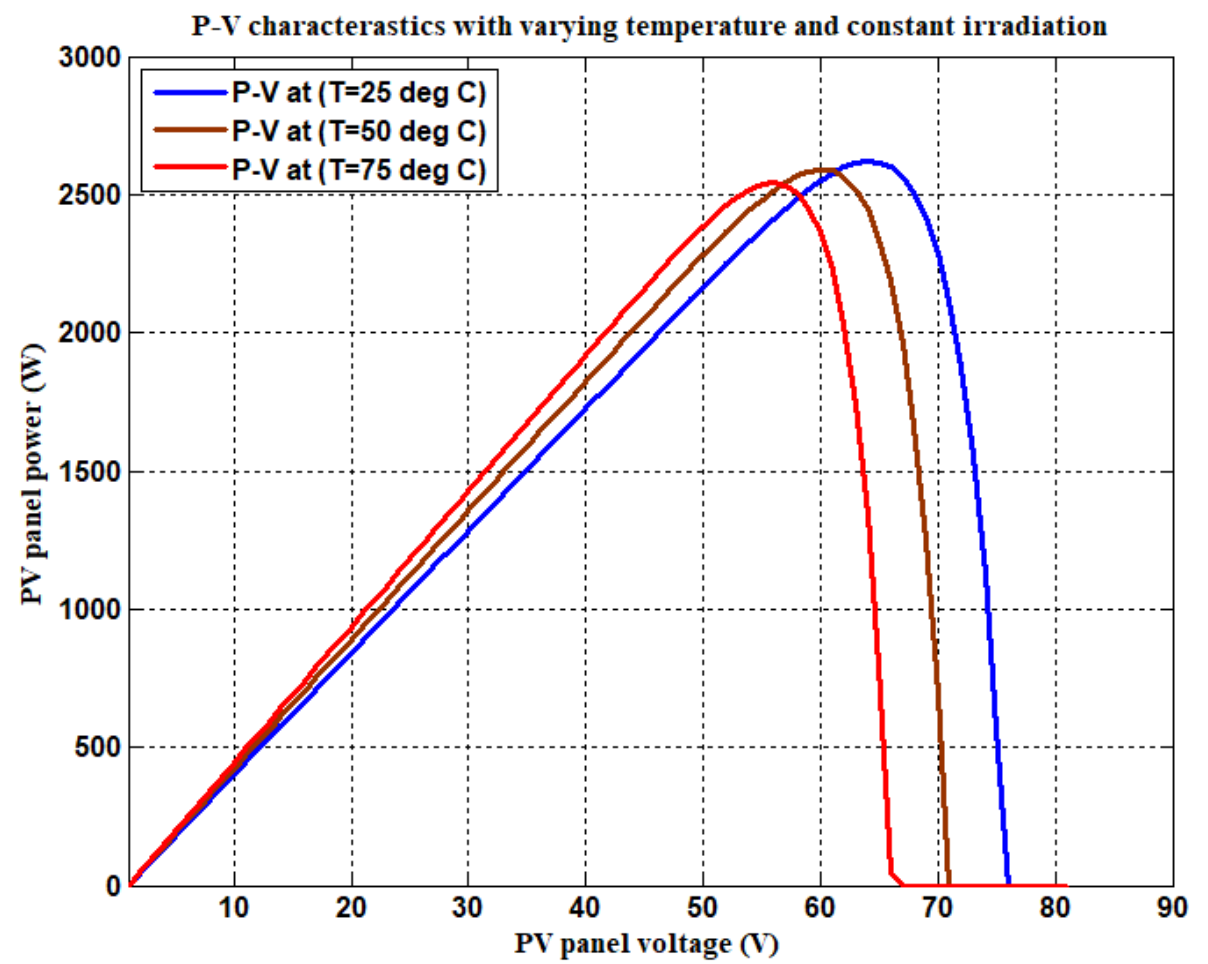

Fig. $6 \mathrm{P}-\mathrm{V}$ characteristic curves at different cells working temperature $\left(T_{c}=25^{\circ} \mathrm{C}, 50^{\circ} \mathrm{C}, 75^{\circ} \mathrm{C}\right)$ for 6 modules in parallel.

\section{Design and Simulation of PV System Using PVsyst Software}

The final system design is performed using the PVsyst V6.43 simulation software (Fig. 7). PVsyst software is a PC package for analyzing the potential of a photovoltaic system at a known location. It consists of both meteorological data and the possibility to select system components from various manufacturers. PVsyst displays the simulation results of designed PV system comprehensively through the created report.

Fig. 8 gives the PV module and battery specification for modeling of standalone system. As per technical specifications, battery used is $12 \mathrm{~V}, 296 \mathrm{Ah}$, which can store energy of $1.184 \mathrm{kWh}$ and the number of battery required is 4 . The PV module selected is of $435 \mathrm{Wp}$, $61.5 \mathrm{~V}$ with array voltage $61.5 \mathrm{~V}$, array current 36.9 A. Array power (STC) generated is $2.6 \mathrm{kWp}$.The number of modules required as per calculation is 6 . Design of solar PV standalone system evaluation mode is shown in Fig. 9. PVsyst provides a detailed analysis of all losses flow diagram of the system as shown in Fig. 10.

Fig. 11 gives the normalized power production and loss factor which is yielding annually. Table 5 gives the balance and main results: annual global horizon is 2,121.8, available solar energy is 4,588.8, unused energy is 451.93, and load connected is 4,029.6. 


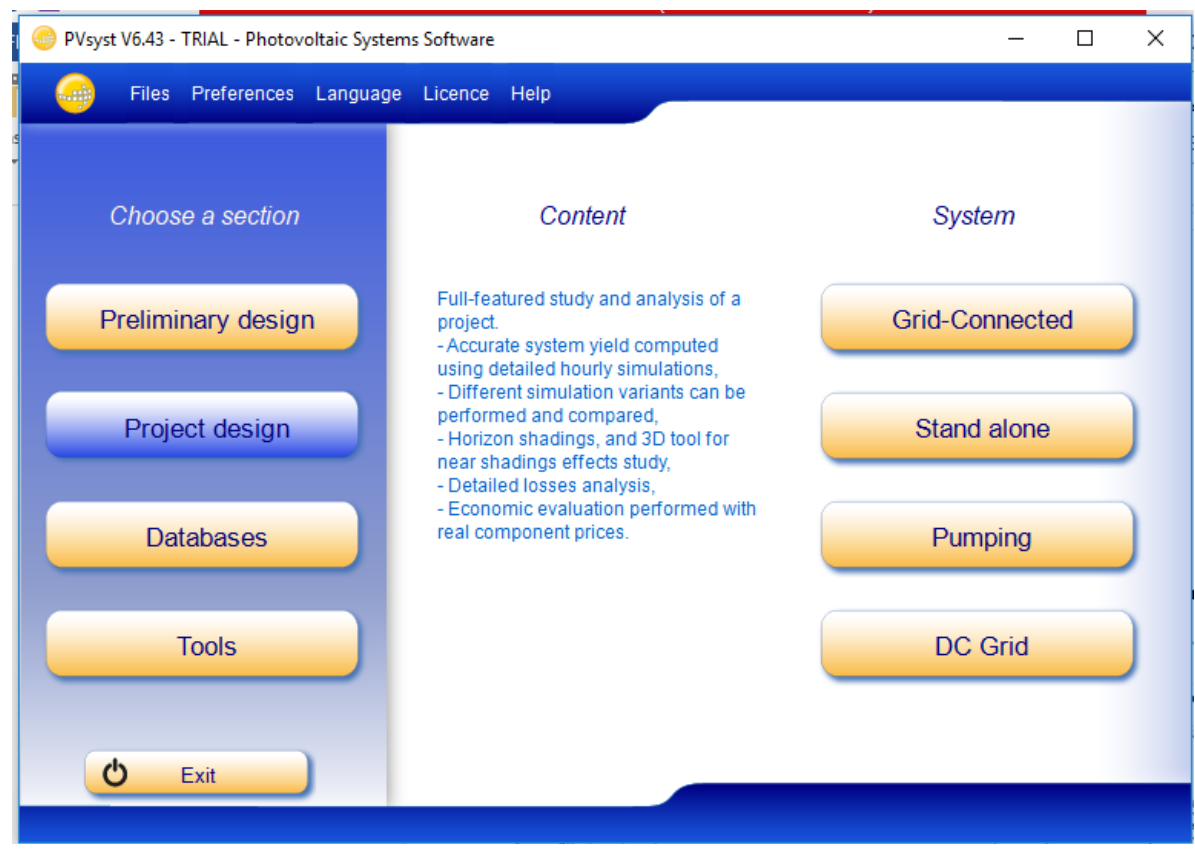

Fig. 7 PVsyst V6.43 simulation software.

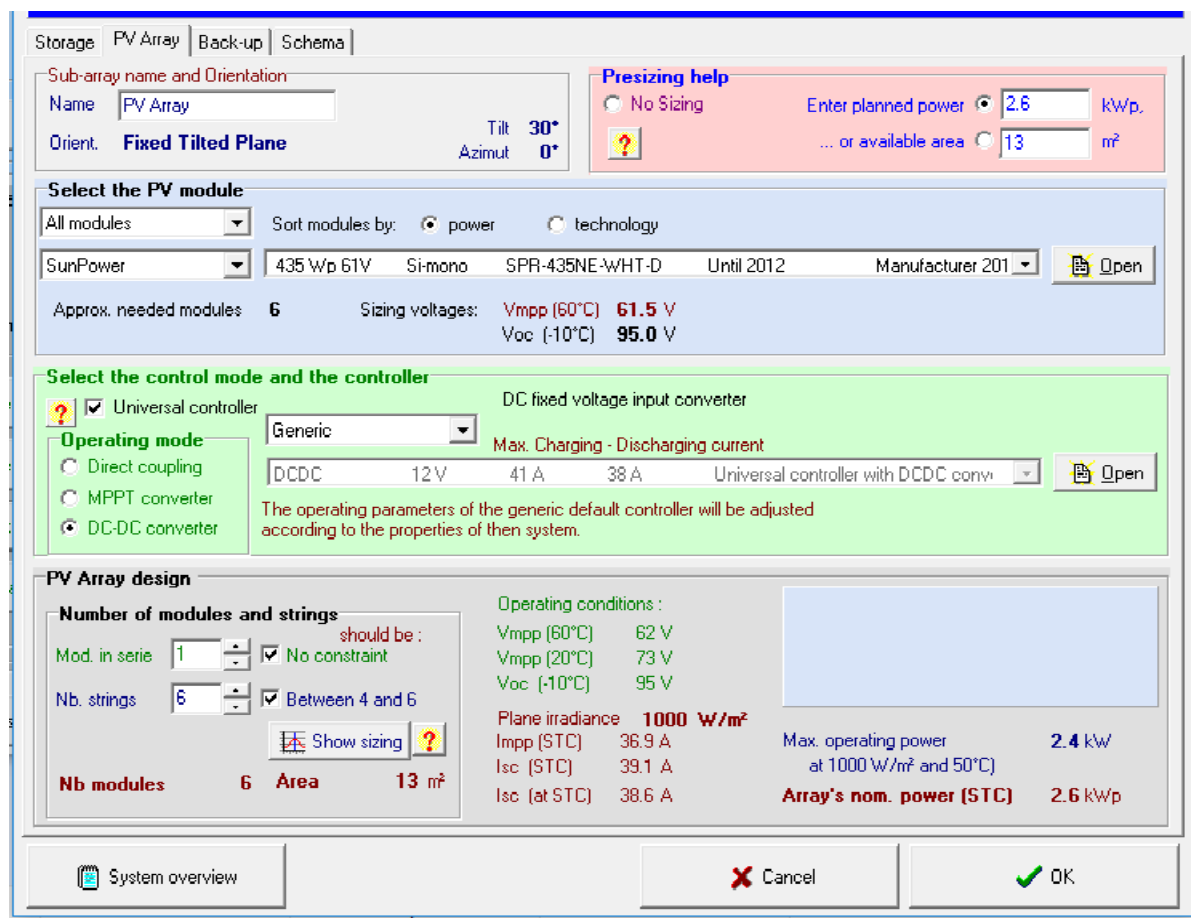

Fig. 8 System design in PVsyst. 

Underground Pipelines in Libya

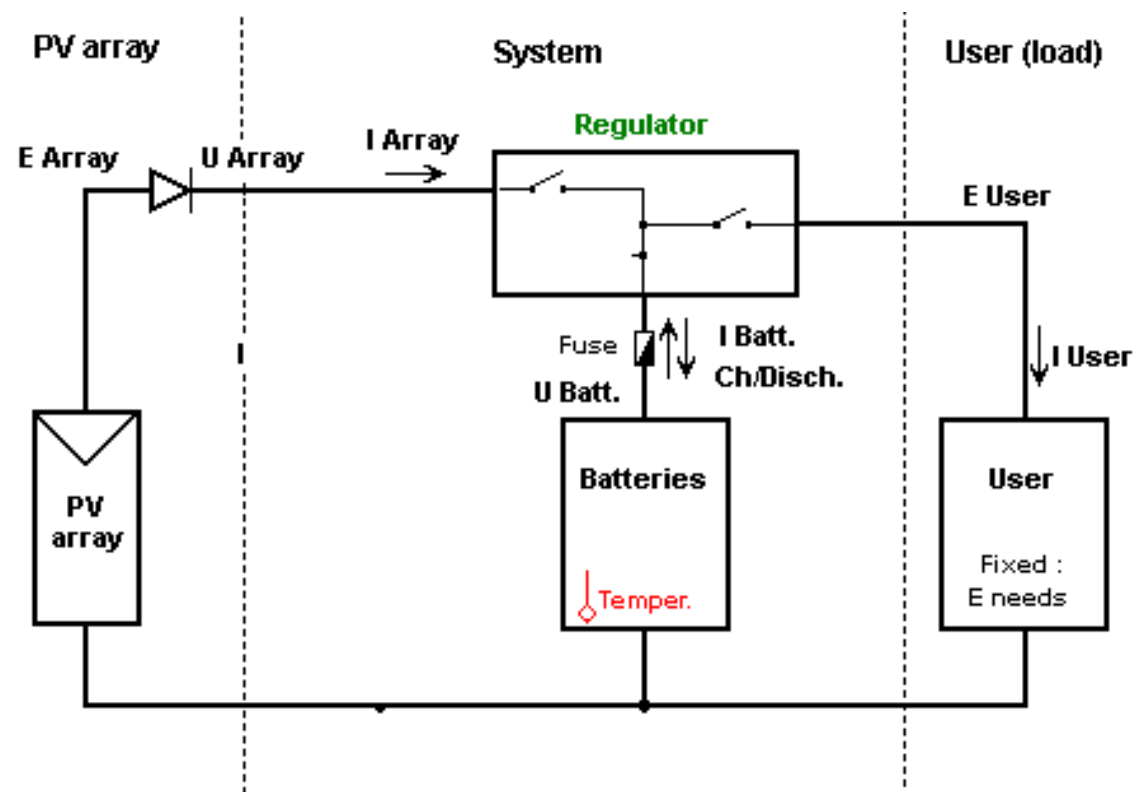

Fig. 9 Typical layout of PV system.

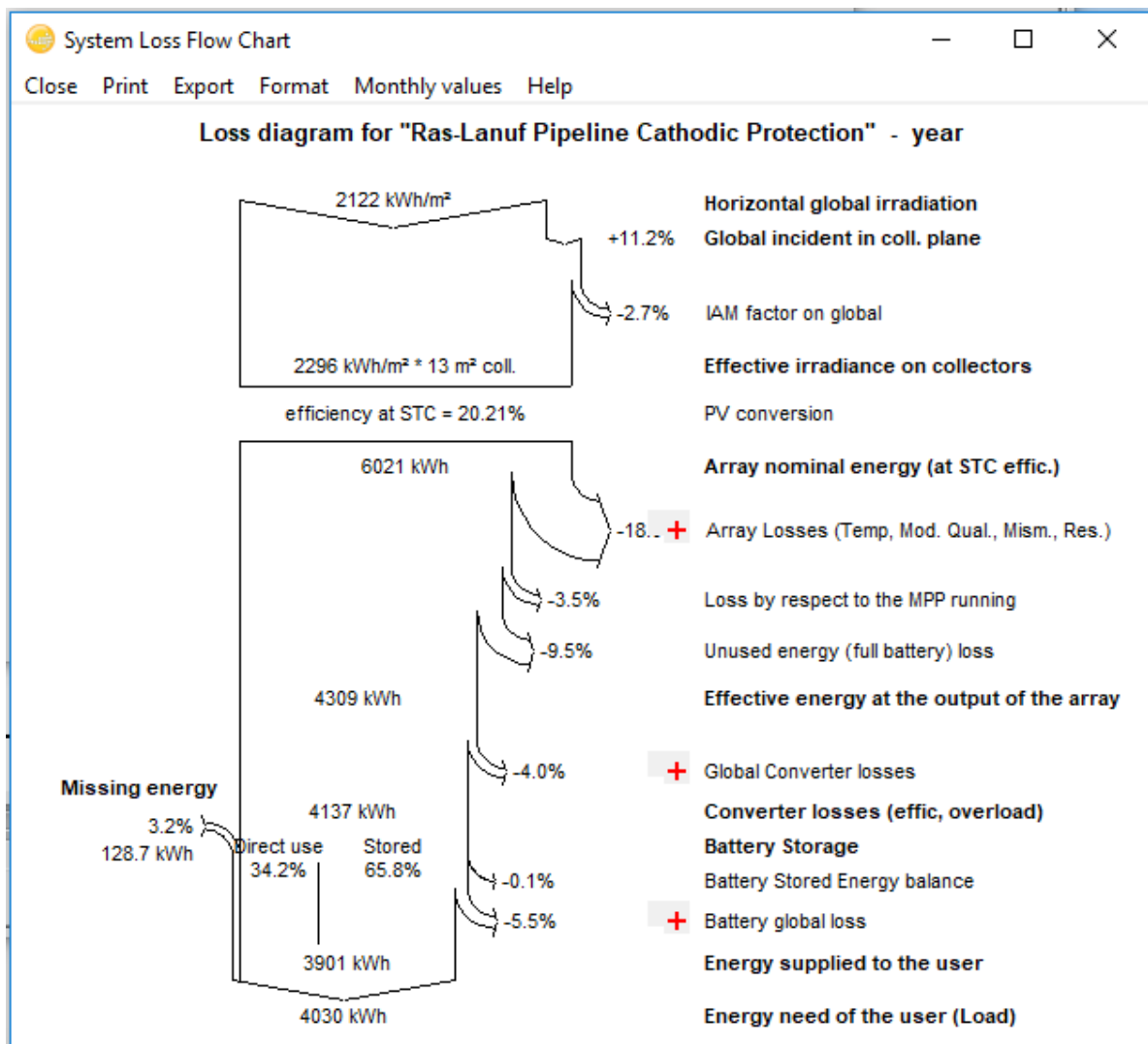

Fig. 10 System loss flow diagram. 

Underground Pipelines in Libya

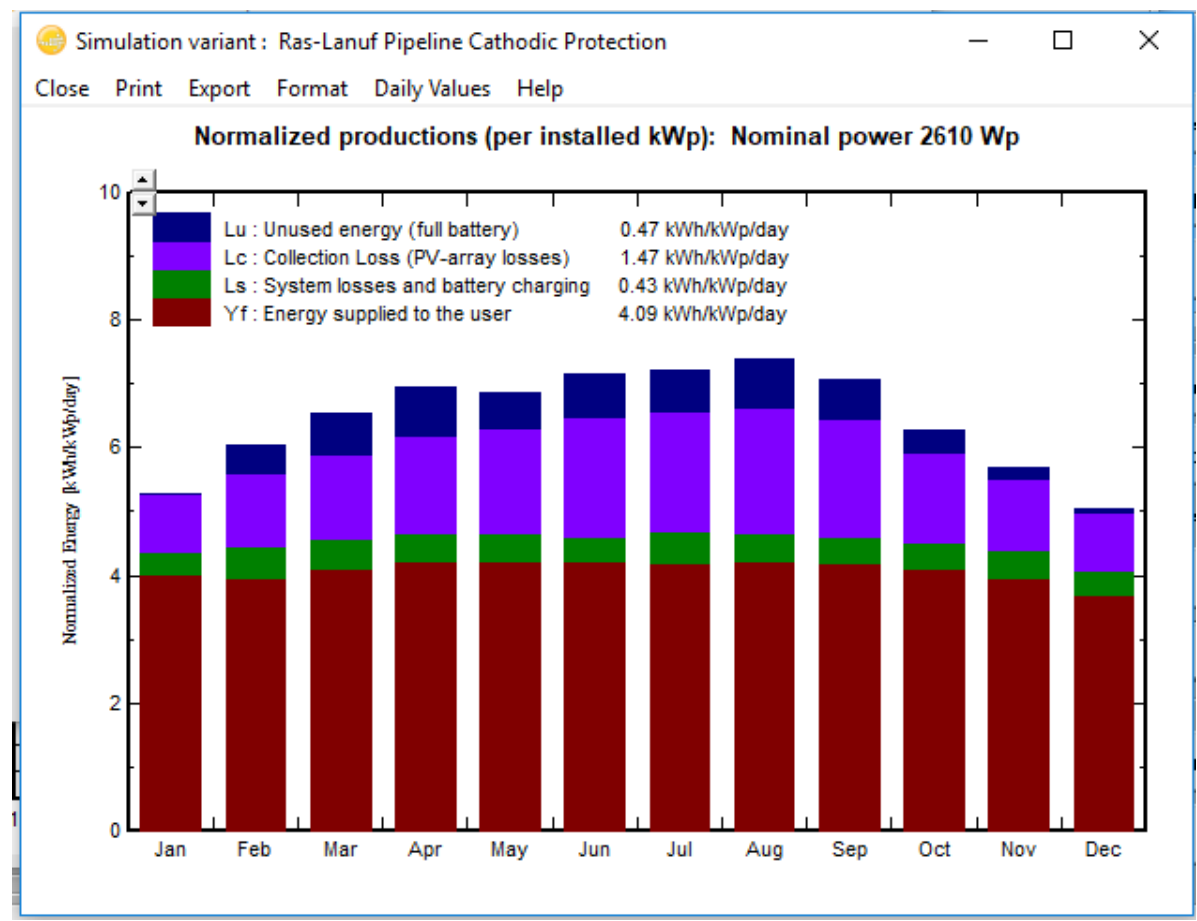

Fig. 11 Normalized production per installed $\mathrm{kWp}$.

Table 5 Balance and main results.

\begin{tabular}{|c|c|c|c|c|c|c|c|c|}
\hline \multicolumn{7}{|c|}{$\begin{array}{l}\text { Simulation variant: Ras-Lanuf Pipeline Cathodic Protection } \\
\text { Close Print Export Help }\end{array}$} & \multicolumn{2}{|c|}{$-\quad \square$} \\
\hline \multicolumn{9}{|c|}{$\begin{array}{l}\text { Ras-Lanuf Pipeline Cathodic Protection } \\
\text { Balances and main results }\end{array}$} \\
\hline & $\begin{array}{l}\text { GlobHor } \\
\mathrm{kW} / \mathrm{mr}^{2}\end{array}$ & $\begin{array}{l}\text { GlobEff } \\
\mathrm{kW} / \mathrm{m}^{2}\end{array}$ & $\begin{array}{c}\text { E Avail } \\
\text { kWh }\end{array}$ & $\begin{array}{l}\text { EUnused } \\
\text { kWh }\end{array}$ & $\begin{array}{l}\text { E Miss } \\
\text { kWh }\end{array}$ & $\begin{array}{c}\text { E User } \\
\text { kWh }\end{array}$ & $\begin{array}{l}\text { E Load } \\
\text { kWh }\end{array}$ & SolFrac \\
\hline January & 108.2 & 160.2 & 338.7 & 0.02 & 18.25 & 324.0 & 342.2 & 0.947 \\
\hline February & 126.3 & 165.6 & 347.0 & 33.34 & 19.20 & 289.9 & 309.1 & 0.938 \\
\hline March & 172.4 & 198.2 & 408.4 & 52.67 & 9.77 & 332.5 & 342.2 & 0.971 \\
\hline April & 201.9 & 202.6 & 410.6 & 60.16 & 0.00 & 331.2 & 331.2 & 1.000 \\
\hline May & 229.1 & 206.1 & 408.1 & 45.59 & 0.00 & 342.2 & 342.2 & 1.000 \\
\hline June & 245.1 & 208.1 & 399.5 & 54.55 & 0.00 & 331.2 & 331.2 & 1.000 \\
\hline July & 248.6 & 216.6 & 415.0 & 51.17 & 4.07 & 338.2 & 342.2 & 0.988 \\
\hline August & 232.5 & 222.6 & 424.7 & 61.53 & 0.00 & 342.2 & 342.2 & 1.000 \\
\hline September & 189.0 & 206.6 & 394.5 & 47.93 & 3.76 & 327.4 & 331.2 & 0.989 \\
\hline October & 150.3 & 189.8 & 378.2 & 28.10 & 9.63 & 332.6 & 342.2 & 0.972 \\
\hline November & 117.3 & 167.2 & 343.5 & 13.28 & 21.34 & 309.9 & 331.2 & 0.936 \\
\hline December & 101.1 & 152.8 & 320.6 & 3.57 & 42.66 & 299.6 & 342.2 & 0.875 \\
\hline Year & 2121.8 & 2296.4 & 4588.8 & 451.93 & 128.67 & 3900.9 & 4029.6 & 0.968 \\
\hline
\end{tabular}




\section{Conclusion}

The proposed renewable supply is the most viable solution for powering impressed current cathodic protection (ICCP) system, which is available throughout the year. This paper shows that using solar photovoltaic powered cathodic protection for buried pipelines transporting hydrocarbon and other oil products in Libya is feasible. The design was based on the pipeline dimensions, the percentage of protected surface area and the electrical parameters of pipeline surrounding environments.

This paper, also describes that numerical calculation and simulations can be useful tools in the design and evaluation of the cathodic protection of buried pipeline networks. The results show that using solar energy powered cathodic protection system for underground pipelines is practical and very beneficial besides being economical, especially considering the rapid decreasing in the prices of PV systems components and the increasing of its efficiencies and reliability.

In addition to that powering ICCP of the pipeline by renewable energy system will reduce the carbon and other harmful gases emission.

\section{References}

[1] Beavers, J. A., Thompson, N. G., and CC Technologies. 2006. "External Corrosion of Oil and Natural Gas Pipelines.” Corrosion: Environments and Industries 13C: \#05145.

[2] Yang, L. 2008. Techniques for Corrosion Monitoring. Houston: Woodhead Publishing.

[3] Edward, G., and Winston, R. 2010. Corrosion Resistance of Aluminum and Magnesium Alloys Understanding,
Performance, and Testing.

[4] Baboian, R. 1995. Corrosion Tests and Standards: Application and Interpretation. Philadelphia: ASTM, 137-42.

[5] Baboian, R. 1986. "Miniaturised Impressed Current Corrosion Protection Systems: An Application for Platinum Clad Niobium.” Platinum Metals Rev. 30 (2): 63-7.

[6] Mathiazhagan, A. 2010. "Design and Programming of Cathodic Protection for SHIPS.” International Journal of Chemical Engineering and Applications 1 (3).

[7] Bianchetti, R. L. 1967. Control of Pipeline Corrosion. NACE International the Corrosion Society, 1440 South Creek Drive, Houston.

[8] Kean, R. L., and Davies, K. G. "Cathodic Protection." NPL for the Department of Trade and Industry, Update of a DTI Publication First Issued in 1981.

[9] DNV. 1993. "Cathodic Protection Design.” Recommended Practice RP, DVN Corporate Headquarter, Oslo, Norway.

[10] Masadeh, S. 2008. "Computer Application in Pipeline Cathodic Protection Design.” In Proceedings of XI International Corrosion Symposium, Dokuz Eylul University, Izmir, Turkey.

[11] Ezekiel Enterprises, LLC. 2015. "Introduction to Electrical Design for Cathodic Protection Systems.” Ezekiel Enterprises, LLC, Article’s Review.

[12] Dwight, H. B. 1936. "Calculation of Resistance to Ground.” Electrical Engineering 55 (12): 1319-29.

[13] Abdulamer, D. N. 2013. "Effect of Soil Resistivity for Different Geometry Anodes on Design Photovoltaic or Cathodic Protection." Journal of Global Research Analysis 2 (11).

[14] https://us.sunpower.com/sites/default/files/media-library/ data-sheets/sunpower-e-series-commercial-solar-panels-e 20-435-com-datasheet-521912-revb_1.pdf.

[15] Al-Refai, M. A. 2017. "Design and Simulation Analysis of 100MW Grid-Connected Solar Photovoltaic Power System at Tripoli-Libya." International Journal of Electrical and Electronic Engineers 9 (02): 402-16. 